\title{
Fruit Yield and Antioxidant Activity of Pepper Genotypes Subjected to Nitrogen Doses
}

\author{
Michele de Morais ${ }^{1}$, Paloma E. B. Martins ${ }^{2}$, Milson E. Serafim², Walmes M. Zeviani ${ }^{3}$, Kelly L. Araujo ${ }^{4}$, \\ Thiago A. S. Gillio ${ }^{1,4}$, Renê A. S. Campos ${ }^{4} \&$ Leonarda G. Neves ${ }^{1,4}$ \\ ${ }^{1}$ Master in Genetics and Plant Breeding, Mato Grosso State University, Cáceres, MT, Brazil \\ ${ }^{2}$ Federal Institute of Education, Science and Technology of Mato Grosso, Cáceres, Brazil \\ ${ }^{3}$ Departament of Estatistics, Federal University of Paraná, Curitiba, PR, Brazil \\ ${ }^{4}$ Departament of Agronomy, Mato Grosso State University, Cáceres, Brazil \\ Correspondence: Renê A. S. Campos, Department of Agronomy, Mato Grosso State University, Cáceres, MT, \\ 78200-000, Brazil. Tel: 55-65-3221-2847. E-mail: renecampos@unemat.br
}

Received: October 3, 2018

Accepted: November 5, 2018

Online Published: January 15, 2019

doi:10.5539/jas.v11n2p139

URL: https://doi.org/10.5539/jas.v11n2p139

The research is financed by Mato Grosso State Foundation for the Support of Research (FAPEMAT)-process $n^{\circ}$ 224291/2015 and a scholarship was granted by Coordination for Improvement of Higher Education Personnel (CAPES)—process $n^{\circ}$ 1669394/DS.

\begin{abstract}
The present study evaluates the fruit yield and antioxidant activity of pepper genotypes as a function of nitrogen doses. The experiment was conducted in a greenhouse with seven pepper genotypes: two C. annuum (116 and 163), two C. chinense (39 and 118), two C. frutescens (17 and 113), and one C. praetermissum (141), and 11 nitrogen doses $\left(0,1,2,4,8,16,32,64,128,256\right.$ and $\left.512 \mathrm{~N} \mathrm{mg} \mathrm{dm}^{-3}\right)$. Productive parameters were evaluated, and antioxidant compounds were determined by spectrophotometric methods. Genotypes 116 and 163 showed a higher fruit fresh mass, and genotype 141 produced the highest number of fruits per plant. Genotypes 141 and 163 were the earliest. The highest antioxidant activity was obtained in the extracts of fruits of genotype 113 . Nitrogen fertilization did not affect the antioxidant content of fruits. The pepper genotypes of the present study have comparable bioactive compound contents and antioxidant activity. Therefore, they are promising genotypes for the vegetable production sector, with potential for industrial and pharmacological use.
\end{abstract}

Keywords: Capsicum L., earliness, total polyphenols, carotenoids, DPPH

\section{Introduction}

Peppers are considered functional foods because of their physiological and pharmacological properties (Shukla et al., 2016). They are excellent sources of ascorbic acid (vitamin C), carotenoids (provitamin A), tocopherols (vitamin E), flavonoids and capsaicinoids (Wahyuni et al., 2013). These substances have antioxidant properties that act to prevent cancer, cardiovascular diseases, and assist in weight loss, presenting benefits to the cardiovascular and gastrointestinal systems (Luo et al., 2011; Srinivasan, 2016).

Brazil is an important diversity center of peppers. Originated along the Andes, the genus Capsicum expanded clockwise around the Amazon basin, towards the center and southeastern regions of Brazil, then back to West South America and finally to the North, in Central America (Carrizo García et al., 2016). Along the vast Brazilian territory, one can find fruits of different shapes, colors, flavors and pungency.

To preserve the genetic variability and economic sustainability of peppers in southwestern Mato Grosso, a pepper Active Germplasm Bank (AGB) was established, gathering around 300 accessions. We characterized the accessions and estimated their genetic diversity (Campos et al., 2016), with further selection of genotypes resistant to anthracnose (Colletotrichum gloeosporioides) (Maracahipes et al., 2017).

In the last decade, due to the search for yield and quality improvement in peppers, characterization studies in active germplasm banks (AGBs) in Brazil were intensified. Earliness, pest resistance, yield and fruit yield are important for the productive and industrial sectors. However, in the market for fresh vegetables, nutritional value 
and functional properties are traits that add value to these foods. Peppers cultivated in Brazil present great variability in antioxidant content (Agostini-Costa et al., 2015; de Aguiar et al., 2016). Thus, biochemical characterization of genotypes is an important step in breeding programs for the development of commercial hybrids with higher content of bioactive compounds.

In addition to the variability in antioxidant activity among genotypes, nitrogen fertilization is an important factor to be considered in pepper production. Nitrogen is one of the main nutrients in plant development, with important roles in physiological processes. In the cultivation of peppers, plant responses to nitrogen fertilization are varied, resulting in higher, larger, greener plants, with more fruits and higher yield (Sarro et al., 1995). However, nitrogen fertilization can cause changes in the nutritional composition, bioactive compounds content and antioxidant activity of peppers (del Amor et al., 2008). Therefore, the present study evaluates the agronomic characteristics, antioxidant activity and bioactive compounds content as a function of nitrogen fertilization in pepper genotypes from the Active Germplasm Bank of southwestern Mato Grosso.

\section{Method}

\subsection{Germplasm, Experiment Site and Experimental Conditions}

Seven genotypes from a pepper AGB were used in this study for agronomic evaluation and chemical characterization. The selection of accessions considered the anthracnose-resistance and antioxidant activity of pepper genotypes, as determined in previous studies. Table 1 describes the pepper accessions evaluated. The genotypes were subjected to increasing rates of nitrogen fertilization $(0 ; 1 ; 2 ; 4 ; 8 ; 16 ; 32 ; 64 ; 128 ; 256$ and 512 $\mathrm{mg} \mathrm{dm^{-3 }}$ ). The study followed a completely randomized design, crossing seven genotypes and 11 nitrogen doses, with two replicates per combination. The experiment was carried out in a greenhouse in Cáceres-MT $\left(16^{\circ} 12^{\prime} \mathrm{S}\right.$, $57^{\circ} 06^{\prime} \mathrm{W}$, altitude of $176 \mathrm{~m}$ a.s.l.), from June to December 2016.

Table 1. List of pepper (Capsicum spp.) genotypes from southwestern Mato Grosso; botanical name, anthracnose tolerance and high antioxidant activity, as determined in previous studies

\begin{tabular}{|c|c|c|c|}
\hline Genotype & Botanical Name & Anthracnose Tolerance ${ }^{a}$ & Antioxidant Activity ${ }^{b}$ \\
\hline 17 & C. frutescens $\mathrm{L}$. & - & \\
\hline 39 & C. chinense Jacq. & • & \\
\hline 113 & C. frutescens $\mathrm{L}$. & • & \\
\hline 116 & C. annuum $\mathrm{L}$. & • & - \\
\hline 118 & C. chinense Jacq. & - & - \\
\hline 141 & C. praetermissum Heiser \& P.G. Sm. & • & • \\
\hline 163 & C. annuum $\mathrm{L}$. & • & \\
\hline
\end{tabular}

Note. a. Maracahipes et al. (2016), b. Araujo (2015).

\subsection{Seedling Production and Crop Management}

Genotypes were sown in 128-cell expanded polystyrene trays containing commercial substrate. Seedlings were transplanted to pots with $3 \mathrm{dm}^{3}$ soil when reaching $10 \mathrm{~cm}$ in height. Soil moisture was maintained between $55-65 \%$ of the total pot volume. Cultural treatments for greenhouse cultivation were carried out following the recommendation of Novais et al. (1991). The soil used in the experiment was classified as dystrophic Red-Yellow latosol (Pérez et al., 2013), collected in the 0-20 cm depth layer. The substrate used in the experiment had the following physicochemical characteristics: $\mathrm{pH}\left(\mathrm{H}_{2} \mathrm{O}\right)=4.91 ; \mathrm{P}=2.2 \mathrm{mg} \mathrm{dm}^{-3} ; \mathrm{K}=36 \mathrm{mg}$ $\mathrm{dm}^{-3} ; \mathrm{Na}=1.15 \mathrm{mg} \mathrm{dm}{ }^{-3} ; \mathrm{Ca}^{2+}=1.15 \mathrm{cmol}_{\mathrm{c}} \mathrm{dm}^{-3} ; \mathrm{Mg}^{2+}=0.35 \mathrm{cmol}_{\mathrm{c}} \mathrm{dm}^{-3} ; \mathrm{Al}^{3+}=0.20 \mathrm{cmol}_{\mathrm{c}} \mathrm{dm}^{-3} ; \mathrm{H}+\mathrm{Al}=3.8$ $\mathrm{cmol}_{\mathrm{c}} \mathrm{dm}^{-3}$; sum of exchangeable bases $=1.59 \mathrm{cmol}_{\mathrm{c}} \mathrm{dm}^{-3}$; effective cation capacity $=1.79 \mathrm{cmol}_{\mathrm{c}} \mathrm{dm}^{-3}$; cation exchange capacity at $\mathrm{pH} 7.0=5.39 \mathrm{cmol}_{\mathrm{c}} \mathrm{dm}^{-3}$; base saturation index $=26.5 \%$; aluminum saturation index $=$ 11.2\%; O.M. $=0.39 \mathrm{dag} \mathrm{kg}{ }^{-1} ; \mathrm{P}-\mathrm{rem}=45.9 \mathrm{mg} \mathrm{L}^{-1} ; \mathrm{S}=1.8 \mathrm{mg} \mathrm{dm}^{-3} ; \mathrm{B}=0.05 \mathrm{mg} \mathrm{dm}^{-3} ; \mathrm{Cu}=0.46 \mathrm{mg} \mathrm{dm}^{-3} ; \mathrm{Mn}$ $=36.0 \mathrm{mg} \mathrm{dm}^{-3} ; \mathrm{Fe}=35.9 \mathrm{mg} \mathrm{dm}{ }^{-3} ; \mathrm{Zn}=0.46 \mathrm{mg} \mathrm{dm}^{-3}$ (Raij et al., 2001). Nitrogen fertilization was applied using ammonium nitrate $(33 \% \mathrm{~N})$ as a source, by means of cover fertilization at 5, 33, 64, 78, 107, 134 and 168 days after transplanting.

\subsection{Plant Growth and Fruit Yield}

Fruit fresh and dry mass and number of fruits per plant were evaluated daily, with results reflecting values accumulated throughout the experimental period. Flowering and fruit ripening time were also evaluated daily, 
reflecting the number of days after transplanting for anthesis and ripening of the first fruit. Final plant height and diameter at base height were evaluated 150 days after transplanting of seedlings, at the end of the experimental period.

\subsection{Chemical Characterization}

To evaluate antioxidant compounds, the fruits were macerated in liquid nitrogen and stored at $-80{ }^{\circ} \mathrm{C}$ in ultrafreezer. High-quality reagents were purchased from Sigma-Aldrich (Brazil), Vetec (Vetec/Sigma-Aldrich, Brazil) and Tedia (Brazil). Spectrophotometric evaluations were done in triplicate in a UV-Vis spectrophotometer (Biochrom Libra S60, England).

The antioxidant activity against 2,2-diphenyl-1-picrylhydrazyl (DPPH) radical was evaluated in fresh fruit extracted with ethanol, methanol and acidified methanol (methanol and $1 \% \mathrm{HCl}$ solution). The supernatants were combined to make up the extract. An aliquot of the extract $(100 \mu \mathrm{L})$ was mixed with $3.9 \mathrm{~mL}$ of $60 \mu \mathrm{M} \mathrm{DPPH}$ ethanolic solution (Brand-Williams et al., 1995). The mixture was homogenized and left to rest in the dark for 60 min. The absorbance was measured at $515 \mathrm{~nm}$ in a spectrophotometer. An ascorbic acid curve was used to calibrate the analysis. The results were expressed as ascorbic acid equivalents (AAE). The assay was performed using extracts at the concentrations of 2,4 and $8 \mathrm{mg} \mathrm{mL}^{-1}$ to determine the inhibitory concentration $\left(\mathrm{IC}_{50}\right)$ of extracts.

Total polyphenols were analyzed in the same extract described above. An aliquot of the extract $(100 \mu \mathrm{L})$ was mixed with $900 \mu \mathrm{L}$ of distilled water, $500 \mu \mathrm{L}$ of $10 \%$ Folin-Ciocalteau and $2.5 \mathrm{~mL}$ of $20 \%$ sodium carbonate. The mixture was homogenized and left to rest in the dark for $60 \mathrm{~min}$. The absorbance was measured at $750 \mathrm{~nm}$ in a spectrophotometer (Singleton \& Rossi, 1965). A gallic acid curve was used to calibrate the analysis. The results were expressed as gallic acid equivalents (GAE). Flavonoids and anthocyanins were analyzed in fresh fruit extracted with acidified ethanol [Ethanol and $1.5 \mathrm{M} \mathrm{HCl}(85: 15 \mathrm{v}: \mathrm{v})$ ]. Extraction was repeated twice, and the supernatants combined. The absorbances were measured at $374 \mathrm{~nm}$ and $535 \mathrm{~nm}$ in a spectrophotometer (Francis, 1982). Flavonoid and anthocyanin contents were determined according to the equations below, and results were expressed as $\mathrm{mg} 100 \mathrm{~g}^{-1}$.

$$
\begin{gathered}
\text { Flavonoids }=\frac{\mathrm{A}_{374} \times \mathrm{DF}}{76.5} \\
\text { Anthocyanins }=\frac{\mathrm{A}_{535} \times \mathrm{DF}}{98.2} \\
\quad \mathrm{DF}=100 /(\mathrm{v} / \mathrm{w})
\end{gathered}
$$

where, A: absorbance values at 374 and $535 \mathrm{~nm}$, DF: dilution factor, v: extraction volume (mL), m: fresh weigth (g) used in the extraction.

$\beta$-carotene and lycopene contents were determined in fresh samples extracted with $4 \mathrm{~mL}$ acetone and $6 \mathrm{~mL}$ hexane. The mixture was homogenized in a Turrax homogenizer. The supernatant was collected, and the absorbances were measured at $453 \mathrm{~nm}, 505 \mathrm{~nm}, 645 \mathrm{~nm}$ and $663 \mathrm{~nm}$ in a spectrophotometer (Nagata \& Yamashita, 1992). $\beta$-carotene and lycopene contents were determined according to the following equations:

$$
\begin{gathered}
\beta \text {-carotene }=0.216 \cdot \mathrm{A}_{663}-1.22 \cdot \mathrm{A}_{645}-0.304 \cdot \mathrm{A}_{505}+0.452 \cdot \mathrm{A}_{453} \\
\text { Lycopene }=-0.0458 \cdot \mathrm{A}_{663}+0.204 \cdot \mathrm{A}_{645}+0.372 \cdot \mathrm{A}_{505}-0.0806 \cdot \mathrm{A}_{453}
\end{gathered}
$$

where, A: absorbance values at 453, 505, 645 and $663 \mathrm{~nm}$.

Data were analyzed considering the mathematical model for the factorial experiment described above, which establishes terms for the main effect of sources of variation, as well as the interaction between these sources. To accommodate the effect of nitrogen doses, polynomials of up to the 4th degree were used (preferably, selecting the one with the lowest degree possible), which were chosen according to the significance of the F statistic of the analysis of variance. The polynomial curves for the nitrogen effect were crossed with the species effect, generating fitted curves for each genotype. Based on the ANOVA table, when not significant, the interaction was removed, thus remaining the fitting of parallel curves. Residual analysis was carried out to avoid a deviation from the assumptions, which would jeopardize the conclusions. Analyses were performed using R statistical software (V 3.4.1).

\section{Results}

Fruit fresh mass (FFM), fruit dry mass (FDM), number of fruits (NF), flowering time (FT) and ripening time (RT) were different in the pepper genotypes evaluated. Nitrogen fertilization affected most of the yield attributes evaluated, except for FT and RT ( $p>0.05)$. Genotypes interacted with nitrogen fertilization for final plant height 
(FPH) and diameter at base height (DBH), indicating different responses among genotypes for these characteristics in relation to nitrogen fertilization. Genotypes 116 (C. annuum) and 163 (C. annuиm) showed superior results for FFM and FDM (Table 2). In these genotypes, fruit yield, in terms of FFM, exceeded the other evaluated genotypes by 2.5 times. Regarding NF per plant, genotype 141 (C. praetermissum) presented a result 1.5 times higher than genotype 116 (C. annuum). Moreover, genotypes 141 (C. praetermissum) and 163 (C. annuum) showed the lowest FT and RT. In these genotypes, RT was, on average, 58.5\% lower than genotypes 113 (C. frutescens) and 118 (C. chinense), in which fruit ripening occurred 140 days after transplanting.

Table 2. Fruit fresh mass (FFM), fruit dry mass (FDM), number of fruits per plant (NFP), flowering time (FT) and fruit ripening time (RT) in pepper genotypes from southwestern Mato Grosso

\begin{tabular}{|c|c|c|c|c|c|}
\hline Genotype & FFM & FDM & NFP & FT & RT \\
\hline & \multicolumn{3}{|c|}{ - } & \multicolumn{2}{|c|}{ 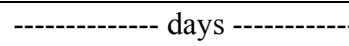 } \\
\hline 17 C. frutescens & $63.4 \mathrm{bc}$ & $8.39 \mathrm{~cd}$ & $6.4 \mathrm{~cd}$ & $49.0 \mathrm{c}$ & $93.4 \mathrm{~b}$ \\
\hline 39 C. chinense & $40.5 \mathrm{c}$ & $5.36 \mathrm{~d}$ & $5.2 \mathrm{~d}$ & $47.9 \mathrm{c}$ & $107.1 \mathrm{~b}$ \\
\hline 113 C. frutescens & $13.3 \mathrm{~d}$ & $2.95 \mathrm{e}$ & $4.3 \mathrm{~d}$ & $63.1 \mathrm{~d}$ & $140.3 \mathrm{c}$ \\
\hline 116 C. аппиит & $85.5 \mathrm{a}$ & $15.4 \mathrm{a}$ & $28.7 \mathrm{~b}$ & $62.7 \mathrm{~d}$ & $112.5 \mathrm{~b}$ \\
\hline 118 C. chinense & $13.1 \mathrm{~d}$ & $2.75 \mathrm{e}$ & $3.2 \mathrm{~d}$ & $72.2 \mathrm{e}$ & $142.2 \mathrm{c}$ \\
\hline 141 C. praetermissum & $27.8 \mathrm{bc}$ & $6.18 \mathrm{bc}$ & $45.7 \mathrm{a}$ & $10.8 \mathrm{a}$ & $60.0 \mathrm{a}$ \\
\hline 163 С. аппиит & $69.5 \mathrm{ab}$ & $13.4 \mathrm{ab}$ & $11.3 \mathrm{c}$ & $30.8 \mathrm{~b}$ & $57.2 \mathrm{a}$ \\
\hline
\end{tabular}

Note. Means followed by the same letter in the columns do not differ at $\mathrm{p}>0.05$ according to the Tukey test.

In the evaluation of the vegetative growth of pepper genotypes, genotype $C$. annuum showed exponential response of FPH as a function of increasing nitrogen rates, with the highest increase in FPH among the evaluated genotypes. The FPH of genotype 113 (C. frutescens) also stood out among genotypes, with cubic response to fertilization (Figure 1A). Accession 141 (C. praetermissum) showed a lower FPH response in relation to the other genotypes, with low increase as a function of fertilization. Regarding $\mathrm{DBH}$, the highest increases as a function of nitrogen fertilization occurred in genotypes 17 (C. frutescens), 39 (C. chinense) and 113 (C. frutescens) (Figure 1B).

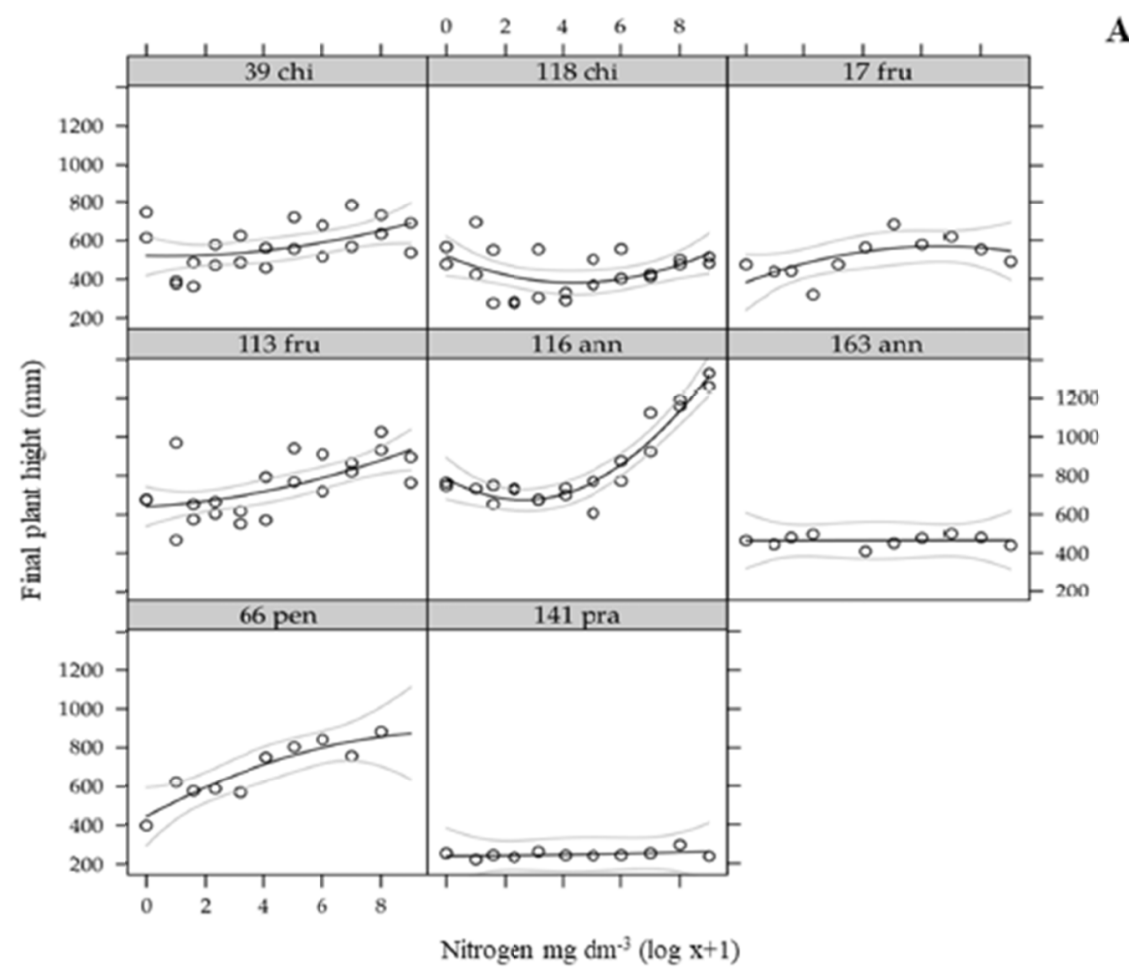




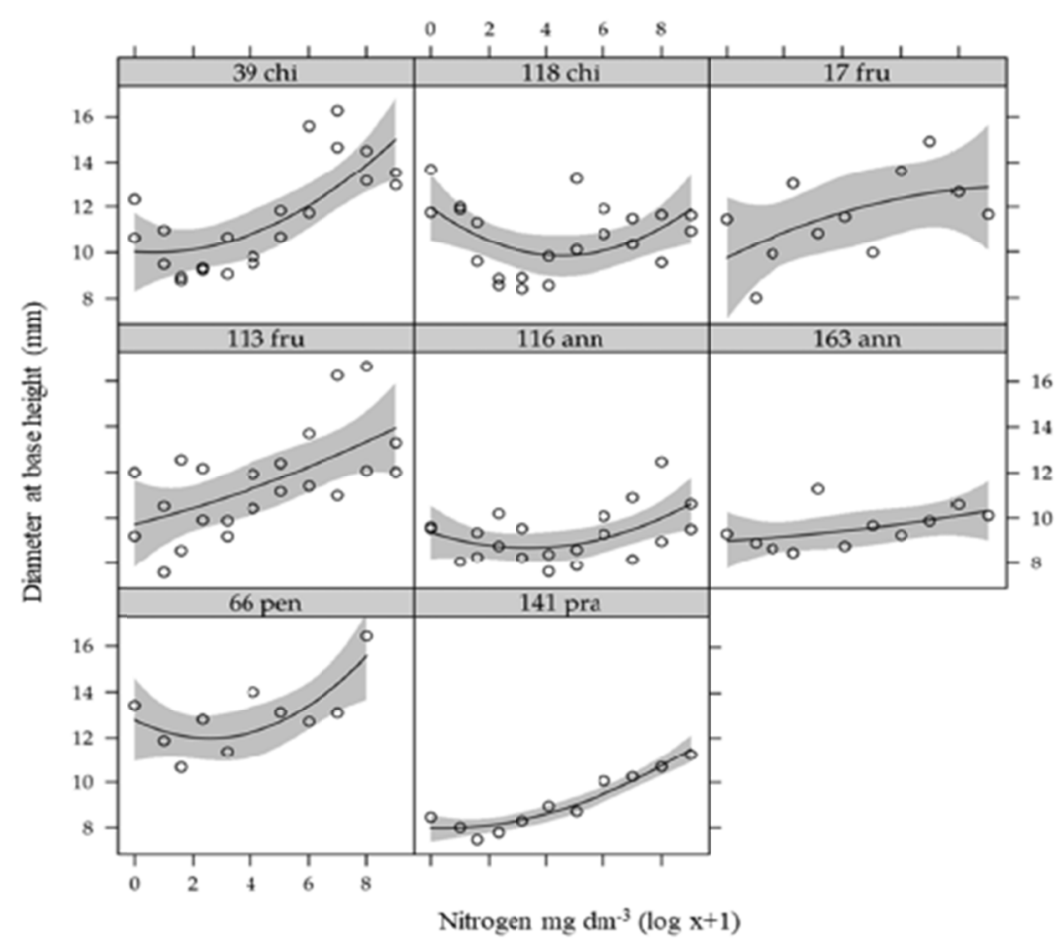

Figure 1. Final plant height (A) and diameter at base height (B) as a function of nitrogen fertilization $\left(\mathrm{mg} \mathrm{dm}^{-3}\right)$ in different pepper genotypes from southwestern Mato Grosso. Each plot represents a specific response of a pepper genotype to increasing doses of nitrogen fertilization

The genotypes presented differences in the antioxidant activity of extracts against the DPPH radical and in the evaluated contents of bioactive compounds. Nitrogen fertilization did not affect the antioxidant activity and bioactive contents $(\mathrm{p}>0.05)$. In terms of the antioxidant activity expressed in ascorbic acid equivalent (AAE), genotype 113 (C. frutescens) presented a superior response among genotypes (Table 3). In this genotype, the antioxidant activity was, on average, 130\% higher compared to genotypes 39 (C. chinense), 118 (C. chinense) and 163 (C. annuum). Genotypes 17 (C. frutescens), 116 (C. annuum) and 141 (C. praetermissum) presented lower antioxidant activity, representing, on average, only $65 \%$ of the response observed in genotype $113(C$. frutescens).

The inhibitory concentration $\left(\mathrm{IC}_{50}\right.$ ) values of the pepper extracts were below $5.0 \mathrm{mg} \mathrm{mL}^{-1}$, indicating a very expressive antioxidant activity in these foods (Table 3). Genotype 113 (C. frutescens) showed antioxidant activity two times higher than genotypes 17 (C. frutescens), 116 (C. annuum) and 141 (C. praetermissum). In addition, genotype 113 (C. frutescens) showed antioxidant activity 1.5 times higher than genotypes 39 ( $C$. chinense), 118 (C. chinense) and 163 (C. annuum), standing out in relation to the functional potential of peppers compared to the other genotypes evaluated.

Genotypes with superior antioxidant activity, e.g. 113 (C. frutescens) and 163 (C. annuum) showed quadratic responses of DPPH radical inhibition, indicating a more intense antioxidant activity at concentrations close to 5.0 $\mathrm{mg} \mathrm{mL} \mathrm{m}^{-1}$, in which approximately $50 \%$ of the free radicals were inhibited (Figure 2). The genotypes with lower antioxidant activity presented linear responses of inhibition of free radicals with increased extract concentration. 
Table 3. Antioxidant activity against 2,2-diphenyl-1-picrylhydrazyl (DPPH) radical and inhibitory concentration $\left(\mathrm{IC}_{50}\right)$ of pepper extracts in different genotypes from southwestern Mato Grosso

\begin{tabular}{lll}
\hline Genotype & Antioxidant Activity-DPPH & $\mathrm{IC}_{50}$ \\
\hline & ------ AAE $\mathrm{mg} 100 \mathrm{~g}^{-1}------$ & $--------\mathrm{mg} \mathrm{mL}^{-1}$-------- \\
17 C. frutescens & $22.9 \mathrm{c}$ & 4.26 \\
39 C. chinense & $28.8 \mathrm{~b}$ & 2.86 \\
113 C. frutescens & $37.0 \mathrm{a}$ & 1.91 \\
116 C. annuum & $25.4 \mathrm{c}$ & 3.27 \\
118 C. chinense & $28.4 \mathrm{~b}$ & 2.77 \\
141 C. praetermissum & $23.1 \mathrm{c}$ & 4.37 \\
163 C. annuum & $30.7 \mathrm{~b}$ & 2.66 \\
\hline
\end{tabular}

Note. Means followed by the same letter in the columns do not differ at $\mathrm{p}>0.05$ according to the Tukey test. $\mathrm{IC}_{50}$ : extract concentration required to inhibit $50 \%$ of DPPH radical.

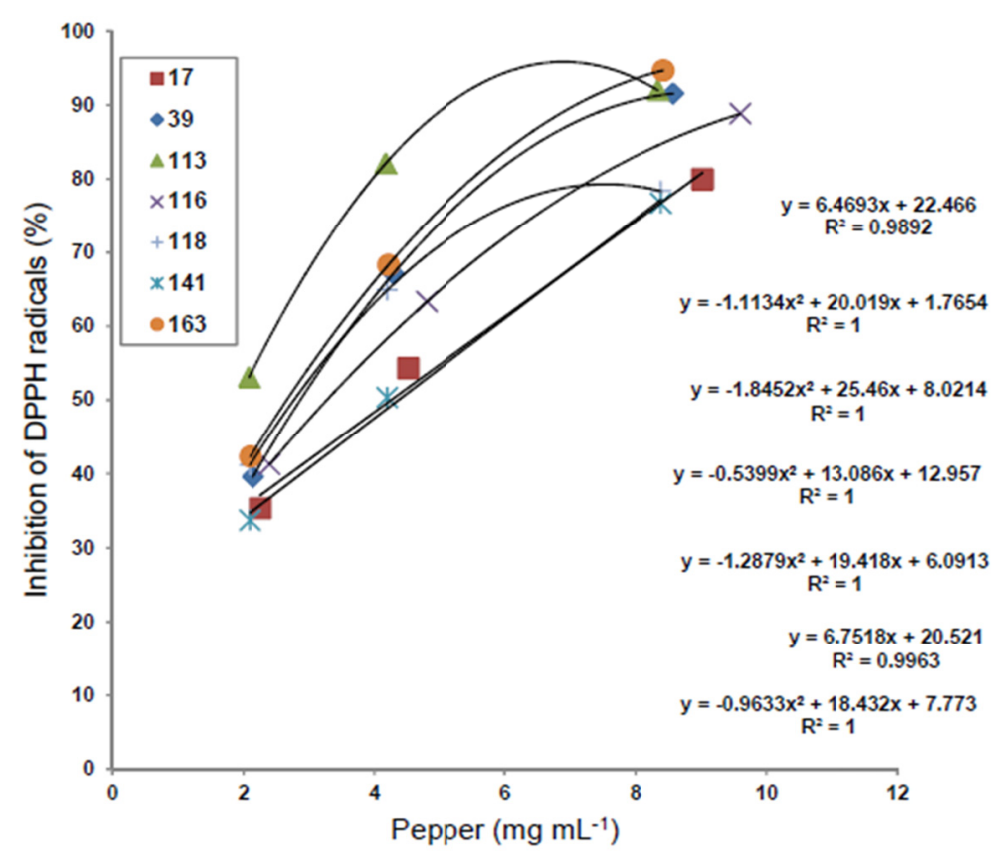

Figure 2. Percent inhibition of 2,2-diphenyl-1-picrylhydrazyl (DPPH) radicals as a function of the concentration of pepper extracts in different genotypes from southwestern Mato Grosso. The inhibitory concentration $\left(\mathrm{IC}_{50}\right)$ is equivalent to the inhibition of $50 \%$ of DPPH radicals

Regarding total polyphenol contents, genotypes 141 (C. praetermissum), 163 (C. annuum) and 113 (C. frutescens) presented higher levels than the other genotypes (Table 4). Genotype 113 (C. frutescens) also presented higher contents of flavonoids, together with genotypes 118 (C. chinense) and 163 (C. annuum). Genotype 163 (C. annuum) also stood out in relation to anthocyanins content, along with genotype 39 ( $C$. chinense). Regarding pigments, genotype 163 (C. annuum) presented the highest content of $\beta$-carotene. Moreover, this genotype also had higher lycopene content, along with genotype 141 (C. praetermissum). 
Table 4. Total polyphenols (TP), flavonoids (FV), anthocyanins (AN), $\beta$-carotene $(\beta \mathrm{C})$ and lycopene (LC) in pepper fruits of different genotypes from southwestern Mato Grosso

\begin{tabular}{|c|c|c|c|c|c|}
\hline Genotype & TP & $\mathrm{FV}$ & AN & $\beta \mathrm{C}$ & $\mathrm{LC}$ \\
\hline & \multicolumn{5}{|c|}{------------------------------------------- mg 100 g } \\
\hline 17 C. frutescens & $36.0 \mathrm{c}$ & $22.4 \mathrm{bc}$ & $9.65 \mathrm{~b}$ & $1.48 \mathrm{~b}$ & $0.52 \mathrm{bc}$ \\
\hline 39 C. chinense & $131.8 \mathrm{~b}$ & $22.9 \mathrm{bc}$ & $10.33 \mathrm{ab}$ & 0.73 cde & $0.36 \mathrm{c}$ \\
\hline 113 C. frutescens & $148.9 \mathrm{ab}$ & $28.3 \mathrm{ab}$ & $4.77 \mathrm{~cd}$ & $1.06 \mathrm{bd}$ & $0.52 \mathrm{bc}$ \\
\hline 116 C. annuum & $138.3 \mathrm{~b}$ & $20.9 \mathrm{c}$ & $2.53 \mathrm{~d}$ & $0.20 \mathrm{e}$ & $0.12 \mathrm{~d}$ \\
\hline 118 C. chinense & $131.2 \mathrm{~b}$ & $28.4 \mathrm{ab}$ & $5.91 \mathrm{c}$ & $0.75 \mathrm{~d}$ & $0.38 \mathrm{c}$ \\
\hline 141 C. praetermissum & $208.5 \mathrm{a}$ & $22.3 \mathrm{bc}$ & $7.65 \mathrm{bc}$ & $1.57 \mathrm{bc}$ & $0.72 \mathrm{ab}$ \\
\hline 163 C. annuum & $175.9 \mathrm{ab}$ & $34.9 \mathrm{a}$ & $13.17 \mathrm{a}$ & $2.45 \mathrm{a}$ & $0.94 \mathrm{a}$ \\
\hline
\end{tabular}

Note. Means followed by the same letter in the columns do not differ at $\mathrm{p}>0.05$ according to the Tukey test.

\section{Discussion}

The present study aimed to describe the main agronomic characteristics of selected pepper genotypes adapted to the climatic conditions of southwestern Mato Grosso. In general, the results of fruit production (FFM per plant) in the pepper genotypes were lower than those available in the literature. As yield is mainly dependent on pepper species, an intraspecies comparison might be more representative.

In $C$. annuum, fruit yield varies between 290-650 g per plant (Nunes Júnior et al., 2017). In C. chinense, fruit yield is similar, ranging from 280-570 g per plant (Domenico et al., 2012). In traditional varieties of $C$. chinense, fruit yield was, on average, $380 \mathrm{~g}$. However, these varieties presented great variation for fruit yield, ranging between 70-1920 g per plant (Araújo et al., 2018), indicating large amplitude for this characteristic.

Similar results were observed in C. praetermissum genotypes, which produced between $42-340 \mathrm{~g}$. Fresh fruit yield in protected environment can reach more than $1 \mathrm{~kg}$ per plant in C. annuum (Oliveira et al., 2013). Under special management conditions, fruit fresh mass in this species may exceed $2 \mathrm{~kg}$ (Campos et al., 2008).

Earliness was a prominent feature among the genotypes of the present study. The results of flowering and ripening time of the obtained fruits are superior to those reported in the literature for peppers. Undoubtedly, genotype 141 (C. praetermissum) stood out in terms of earliness, flowering in 11 days, that is, a little more than a week after the transplanting of seedlings. In turn, the other pepper genotypes evaluated flowered, on average, in 55 days. In $C$. chinense, the flowering time is 95 days (Domenico et al., 2012). In C. praetermissum, flowering and fruit ripening time are 81 and 101 days, respectively (Ferraz et al., 2016).

As stated earlier, characteristics such as pest resistance, yield and uniformity are important for the productive and industrial sectors. In addition to these characteristics, the search for early materials has guided Brazilian studies on pepper genotypes characterization. Earliness is an important attribute for pepper producers, because when hybrids are available at an earlier stage, two or three plantations can be managed in a single year, with further possibility of making the planting schedule more flexible (Rodrigues, 2016).

In times of climate change, it is easier to change the planting schedule by anticipating the first harvest, so that it does not coincide with rainy periods. Thus, earliness can be a very important characteristic for pepper producers in southwestern Mato Grosso and in other regions of Brazil.

Genotypes 116 (C. annuum) and 163 (C. annuum) showed higher production of fruit biomass. Genotype 141 (C. praetermisusum), in turn, produced the highest number of fruits. Moreover, genotypes 141 (C. praetermisusum) and 163 (C. annuum) presented fruit production in less time, indicating a higher earliness.

More detailed studies for the selected pepper genotypes described in the present study are recommended to improve the yield potential. These pepper genotypes are resistant to anthracnose (Maracahipes et al., 2017). Therefore, they are promising genotypes for the vegetable production sector, with potential for industrial and pharmacological use.

Nitrogen fertilization positively affected plant growth without altering antioxidant content. Regarding the growth of pepper genotypes, in general, the results of the present study are similar to those reported by Araújo et al. (2018) and Ferraz et al. (2016). In pepper plants, plant height and stem diameter are strongly influenced by nitrogen fertilization (Oliveira et al., 2013). These characteristics were positively affected by nitrogen 
fertilization in all genotypes studied, but to a lesser extent in genotypes 141 (C. praetermissum) and 163 (C. annuum).

This positive effect of nitrogen fertilization on growth was already expected, since the growth and yield of vegetables are largely affected by the application of nitrogen fertilizers. Ammonium nitrate is the most suitable $\mathrm{N}$ source for pepper crop among commercially available fertilizers (Ghoname et al., 2009). $\mathrm{N}$ is related to the biosynthesis of proteins and carotenoids, and the balance between proteins and carbohydrates (Lawlor et al., 2001). Furthermore, when supplied in sufficient doses, it allows greater development of the photosynthetic surface area in higher plants (Reich et al., 2002).

In addition to positively affecting fruit growth and yield, fertilization can also affect nutritional and functional characteristics in vegetables. In the present study, nitrogen fertilization did not affect the bioactive compounds content evaluated, nor the antioxidant activity of extracts. The effects of preharvest factors on the quality of vegetables were recently reviewed by Poiroux-Gonord et al. (2010). According to the authors, the impact of nitrogen fertilization on the antioxidant content of vegetables is variable and sometimes contradictory.

In $C$. annuum, the increase or decrease of important nutrients in fertilization may alter the levels of vitamin $\mathrm{C}$, $\beta$-carotene and total polyphenols (Marín et al., 2009). In this species, nitrogen fertilization increases anthocyanin and flavonoid content at higher concentrations (del Amor et al., 2009). Notwithstanding, this did not occur in the present study, that is, fertilization did not alter the bioactive compounds content. Núñez-Ramírez et al. (2011) reported a similar result, verifying that nitrogen fertilization does not affect the antioxidant compounds content in $C$. chinense. In our study, the differences between the antioxidant potential occurred only as a function of the different genotypes evaluated.

Antioxidants are substances which retard oxidative degradation reactions by means of different mechanisms, such as inhibition of free radicals and complexation of metals (Sharma et al., 2012). The antioxidant activity of peppers was evaluated by inhibiting the stable free radical 2,2-diphenyl-1-picrylhydrazyl (DPPH). Genotype 113 (C. frutescens) stood out in terms of antioxidant activity. In general, the results obtained are similar to those reported by Gurnani et al. (2016) and Lahbib et al. (2017), who found 10-30\% inhibition of DPPH radicals at the concentration of $1-5 \mathrm{mg} \mathrm{mL}^{-1}$ in extracts of $C$. annuum and C. frutescens.

In terms of $\mathrm{IC}_{50}$, which denotes the concentration required to inhibit $50 \%$ of free radicals, the values obtained in the pepper genotypes of the present study ranged between $1-5 \mathrm{mg} \mathrm{mL}^{-1}$, similar to the $\mathrm{IC}_{50}$ response described by Azeez et al. (2012) for $C$. annuum. However, slightly higher results are reported in peppers, with $\mathrm{IC}_{50}$ between 5-500 $\mu \mathrm{g} \mathrm{mL}^{-1}$ (Loizzo et al., 2015). The lower the $\mathrm{IC}_{50}$ value, the greater the potential of the extract in protecting the cells from oxidative damage.

The ability of antioxidants to react with free radicals can prevent the destructive effects of these radicals and the resulting chronic diseases (Halliwell, 1996). The imbalance between generation and elimination of free radicals in cells has been recognized as one of the most important factors in the development of chronic diseases in recent years (Valko et al., 2016). Some phytochemicals are strong antioxidants and are believed to reduce the risk of chronic diseases by protecting the damage caused by free radicals, modifying metabolic activation and detoxification of carcinogens, or even influencing processes that alter the pathway of cancer cells (Araújo et al., 2011)

Total polyphenol content is often correlated with antioxidant activity against DPPH radical in peppers (Carvalho et al., 2015; Sora et al., 2015). In the present study, total polyphenol content was observed between 10-300 mg $100 \mathrm{~g}^{-1} \mathrm{fw}$, similar to those reported in other studies on peppers (de Aguiar et al., 2016). Regarding flavonoids, genotype 163 (C. annuum) was the genotype with the highest levels of this substance. The results of the present study ranged between $20-35 \mathrm{mg} 100 \mathrm{~g}^{-1} \mathrm{fw}$, being similar to those reported by Lahbib et al. (2017), who found

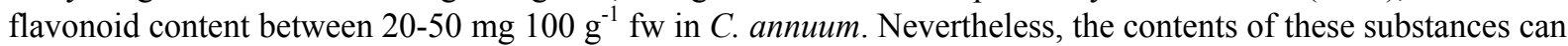
reach 100-120 mg $100 \mathrm{~g}^{-1} \mathrm{fw}$ in C. baccatum and C. annuum (Tundis et al., 2013; Zimmer et al., 2012).

For anthocyanins, in turn, the results of the present study were similar to those reported by Carvalho et al., (2015), ranging between 2-20 mg $100 \mathrm{~g}^{-1} \mathrm{fw}$. Anthocyanins are a group of compounds that are part of the class of flavonoids. Numerous studies confirm that these substances exert a protective action on human health and are key components of a healthy and balanced diet (Seeram et al., 2006).

As for carotenoids, the present study focused on two substances, $\beta$-carotene and lycopene. $\beta$-carotene contents

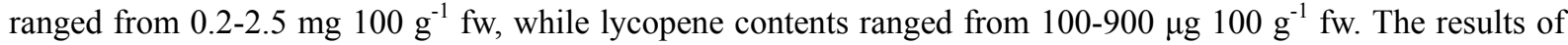
the present study are similar to those found in C. annuum (Hallmann \& Rembiałkowska, 2012). According to Carvalho et al. (2015), total carotenoid content in pepper fruits should vary from $50 \mu \mathrm{g}$ to $1.5 \mathrm{mg}^{100 \mathrm{~g}^{-1}} \mathrm{fw}$. 
The color variation of peppers is attributed to different carotenoid profiles (Nagy et al., 2015). The main carotenoids present in Brazilian cultivars of $C$. annuum and $C$. chinense are $\beta$-carotene, $\alpha$-carotene, capsanthin, violaxanthin, zeaxanthin and $\beta$-cryptoxanthin (Agostini-Costa et al., 2017). In plants, carotenoids are an integral part of the photosynthesis mechanism, whose main function is to protect cells and organelles against oxidative damage by extinguishing singlet oxygen molecules, avoiding accumulation of free radicals (Holt et al., 2005).

In food, $\beta$-carotene has a high activity against oxygen singlet molecules (Wang $\&$ Jiao, 2000). $\beta$-carotene is one of the main food sources of vitamin A, since it is a precursor of this vitamin. Vitamin A functions include regulating hormone synthesis, improving the immune system, as well as skin cell growth and differentiation (Bartley, 1995).

Lycopene is another liposoluble compound, which although not having provitamin A activity, is highly stable and of great importance for processed foods. Lycopene is effective in preventing chronic diseases such as cancer, especially prostate cancer, cardiovascular diseases, among others (Leong et al., 2018).

Peppers are considered foods rich in carotenoids. Mokhtar et al. (2015) demonstrated that the antioxidant activity of carotenoids present in C. annuum is superior to the activity of capsaicinoids. According to the authors, this response explains the marked anticancer activity of these substances.

Thus, the pepper genotypes evaluated in the present study presented antioxidant activity comparable to other genotypes of peppers reported in the literature. Due to the bioactive compounds content and the antioxidant activity presented, these peppers constitute good alternatives for the vegetable market and for industrial use.

\section{Conclusion}

Genotypes 116 (C. annuum) and 163 (C. annuum) showed higher fruit biomass, while genotype 141 (C. praetermisusum) produced the highest number of fruits and was the earliest. The highest antioxidant activity was obtained in the extracts of fruits of genotype 113 (C. frutescens). The level of nitrogen fertilization did not affect the antioxidant content of fruits.

The genotypes of the present study have antioxidant activity similar to other pepper genotypes already reported in the literature. These peppers constitute good alternatives for consumers seeking higher-quality food. Moreover, the genotypes can be used in breeding programs for the development of new commercial hybrids with superior antioxidant activity and high levels of substances with biological activity.

\section{References}

Agostini-Costa, T., da Silva Gomes, I., de Melo, L. A. M. P., Reifschneider, F. J. B., \& da Costa Ribeiro, C. S. (2017). Carotenoid and total vitamin C content of peppers from selected Brazilian cultivars. Journal of Food Composition and Analysis, 57, 73-79. https://doi.org/10.1016/j.jfca.2016.12.020

Araújo, C. M., Silva Filho, D. F., Ticona-Benavente, C. A., \& Batista, M. R. A. (2018). Morphoagronomic characteristics display high genetic diversity in Murupi chili pepper landraces. Horticultura Brasileira, 36(1), 83-87. https://doi.org/10.1590/s0102-053620180114

Araújo, J. R., Gonçalves, P., \& Martel, F. (2011). Chemopreventive effect of dietary polyphenols in colorectal cancer cell lines. Nutrition Research, 31(2), 77-87. https://doi.org/10.1016/j.nutres.2011.01.006

Araújo, L. M. (2015). Identification of genotypes with high concentration of antioxidant compounds in fruits of access Capsicum spp. the AGB of UNEMAT (Unpublished master's thesis, Mato Grosso State University, Cáceres, MT, Brazil).

Azeez, L., Adeoye, M. D., Majolagbe, T. A., Lawal, A. T., \& Badiru, R. (2012). Antioxidant activity and phytochemical contents of some selected Nigerian fruits and vegetables. American Journal of Chemistry, 2(4), 209-213. https://doi.org/10.5923/j.chemistry.20120204.04

Bartley, G. E. (1995). Plant carotenoids: Pigments for photoprotection, visual attraction, and human health. The Plant Cell Online, 7(7), 1027-1038. https://doi.org/10.1105/tpc.7.7.1027

Brand-Williams, W., Cuvelier, M. E., \& Berset, C. (1995). Use of a free radical method to evaluate antioxidant activity. LWT-Food Science and Technology, 28(1), 25-30. https://doi.org/10.1016/S0023-6438(95)80008-5

Campos, A. L., Marostega, T. N., Cabral, N. S. S., Araújo, K. L., Serafim, M. E., Seabra-Júnior, S., ... Neves, L. G. (2016). Morphoagronomic and molecular profiling of Capsicum spp. from southwest Mato Grosso, Brazil. Genetics and Molecular Research, 15(3), 1-12. https://doi.org/10.4238/gmr.15038167

Campos, V. B., Oliveira, A. P., Cavalcante, L. F., \& Prazeres, S. S. (2008). Yield of pepper submitted to nitrogen applied through irrigation water in protected environment. Revista de Biologia e Ciências Da Terra, 8(2), 
$72-79$.

Carrizo García, C., Barfuss, M. H. J., Sehr, E. M., Barboza, G. E., Samuel, R., Moscone, E. A., \& Ehrendorfer, F. (2016). Phylogenetic relationships, diversification and expansion of chili peppers (Capsicum, Solanaceae). Annals of Botany, 118(1), 35-51. https://doi.org/10.1093/aob/mcw079

Carvalho, A. V., de Andrade Mattietto, R., de Oliveira Rios, A., de Almeida Maciel, R., Moresco, K. S., \& de Souza Oliveira, T. C. (2015). Bioactive compounds and antioxidant activity of pepper (Capsicum sp.) genotypes. Journal of Food Science and Technology, 52(11), 7457-7464. https://doi.org/10.1007/s13197015-1833-0

Chávez-Mendoza, C., Sanchez, E., Muñoz-Marquez, E., Sida-Arreola, J., \& Flores-Cordova, M. (2015). Bioactive compounds and antioxidant activity in different grafted varieties of bell pepper. Antioxidants, 4(2), 427-446. https://doi.org/10.3390/antiox4020427

de Aguiar, A. C., Coutinho, J. P., Barbero, G. F., Godoy, H. T., \& Martínez, J. (2016). Comparative study of capsaicinoid composition in Capsicum peppers grown in Brazil. International Journal of Food Properties, 19(6), 1292-1302. https://doi.org/10.1080/10942912.2015.1072210

del Amor, F. M., Cuadra-Crespo, P., Varó, P., \& Gómez, M. C. (2009). Influence of foliar urea on the antioxidant response and fruit color of sweet pepper under limited N supply. Journal of the Science of Food and Agriculture, 89(3), 504-510. https://doi.org/10.1002/jsfa.3485

Domenico, C. I., Coutinho, J. P., Godoy, H. T., \& Melo, A. M. de. (2012). Caracterização agronômica e pungência em pimenta de cheiro. Horticultura Brasileira, 30(3), 466-472. https://doi.org/10.1590/S010 2-05362012000300018

Ferraz, R. M., Ragassi, C. F., Heinrich, A. G., Lima, M. F., Peixoto, J. R., \& Reifschneider, F. J. (2016). Caracterização morfoagronômica preliminar de acessos de pimentas cumari. Horticultura Brasileira, 34(4), 498-506. https://doi.org/10.1590/s0102-053620160408

Francis, F. J. (1982). Analysis of anthocyanins. In P. Markakis (Ed.), Anthocyanins as food colors (pp. 181-207). New York: Academic Press.

Ghoname, A. A., Dawood, M. G., Riad, G. S., \& El-Tohamy, W. A. (2009). Effect of nitrogen forms and biostimulants foliar application on the growth, yield and chemical composition of hot pepper grown under sandy soil conditions. Research Journal of Agriculture and Biological Sciences, 5(5), 840-452.

Gurnani, N., Gupta, M., Mehta, D., \& Mehta, B. K. (2016). Chemical composition, total phenolic and flavonoid contents, and in vitro antimicrobial and antioxidant activities of crude extracts from red chilli seeds (Capsicum frutescens L.). Journal of Taibah University for Science, 10(4), 462-470. https://doi.org/10.101 6/j.jtusci.2015.06.011

Halliwell, B. (1996). Oxidative stress, nutrition and health: Experimental strategies for optimization of nutritional antioxidant intake in humans. Free Radical Research, 25(1), 57-74. https://doi.org/10.3109/ 10715769609145656

Hallmann, E., \& Rembiałkowska, E. (2012). Characterisation of antioxidant compounds in sweet bell pepper (Capsicum annuum L.) under organic and conventional growing systems. Journal of the Science of Food and Agriculture, 92(12), 2409-2415. https://doi.org/10.1002/jsfa.5624

Holt, N. E., Zigmantas, D., Valkunas, L., Li, X.-P., Niyogi, K. K., \& Fleming, G. R. (2005). Carotenoid cation formation and the regulation of photosynthetic light harvesting. Science, 307(5708), 433-436. https://doi.org/10.1126/science.1105833

Lahbib, K., Dabbou, S., Bok, S., Pandino, G., Lombardo, S., \& Gazzah, M. (2017). Variation of biochemical and antioxidant activity with respect to the part of Capsicum annuum fruit from Tunisian autochthonous cultivars. Industrial Crops and Products, 104, 164-170. https://doi.org/10.1016/j.indcrop.2017.04.037

Lawlor, D. W., Lemaire, G., \& Gastal, F. (2001). Nitrogen, plant growth and crop yield. In P. J. Lea, \& J. F. Morot-Gaudry (Eds.), Plant Nitrogen (pp. 343-367). Berlin, Heidelberg: Springer, Berlin, Heidelberg. https://doi.org/10.1007/978-3-662-04064-5_13

Leong, H. Y., Show, P. L., Lim, M. H., Ooi, C. W., \& Ling, T. C. (2018). Natural red pigments from plants and their health benefits: A review. Food Reviews International, 34(5), 463-482. https://doi.org/10.1080/ 87559129.2017 .1326935

Loizzo, M. R., Pugliese, A., Bonesi, M., Menichini, F., \& Tundis, R. (2015). Evaluation of chemical profile and 
antioxidant activity of twenty cultivars from Capsicum annuum, Capsicum baccatum, Capsicum chacoense and Capsicum chinense: A comparison between fresh and processed peppers. LWT-Food Science and Technology, 64(2), 623-631. https://doi.org/10.1016/j.lwt.2015.06.042

Luo, X.-J., Peng, J., \& Li, Y.-J. (2011). Recent advances in the study on capsaicinoids and capsinoids. European Journal of Pharmacology, 650(1), 1-7. https://doi.org/10.1016/j.ejphar.2010.09.074

Maracahipes, A. C., Correa, J. W. S., Teodoro, P. E., Araújo, K. L., Barelli, M. A. A., \& Neves, L. G. (2017). Correlation study of resistance components in the selection of Capsicum genotypes resistant to the fungus Colletotrichum gloeosporioides. Genetics and Molecular Research, 16(3), 1-11. https://doi.org/10.4238/ gmr16039720

Maracahipes, Á. C., Viscovini, K. K. C. G., Annunciatto, E. da S., Neves, L. G., Serafim, M. evaldo, da Luz, P. B., \& Araújo, K. L. (2016). Genetic diversity of the germplasm active bank of Capsicum of UNEMAT based on components resistant to the fungus Colletotrichum gloeosporioides. Australian Journal of Crop Science, 10(07), 940-948. https://doi.org/10.21475/ajcs.2016.10.07.p7437

Marín, A., Rubio, J. S., Martínez, V., \& Gil, M. I. (2009). Antioxidant compounds in green and red peppers as affected by irrigation frequency, salinity and nutrient solution composition. Journal of the Science of Food and Agriculture, 89(8), 1352-1359. https://doi.org/10.1002/jsfa.3594

Mokhtar, M., Russo, M., Cacciola, F., Donato, P., Giuffrida, D., Riazi, A., ... Mondello, L. (2016). Capsaicinoids and Carotenoids in Capsicum annuum L.: Optimization of the extraction method, analytical characterization, and evaluation of its biological properties. Food Analytical Methods, 9(5), 1381-1390. https://doi.org/ $10.1007 / \mathrm{s} 12161-015-0311-7$

Nagata, M., \& Yamashita, I. (1992). Simple method for simultaneous determination of chlorophyll and carotenoids in tomato fruit. Nippon Shokuhin Kogyo Gakkaishi, 39(10), 925-928. https://doi.org/ 10.3136/nskkk1962.39.925

Nagy, Z., Daood, H., Ambrózy, Z., \& Helyes, L. (2015). Determination of polyphenols, capsaicinoids, and vitamin $\mathrm{C}$ in new hybrids of chili peppers. Journal of Analytical Methods in Chemistry, 1-10. https://doi.org/10.1155/2015/102125

Neitzke, R. S., Vasconcelos, C. S., Barbieri, R. L., Vizzotto, M., Fetter, M. R., \& Corbelini, D. D. (2015). Variabilidade genética para compostos antioxidantes em variedades crioulas de pimentas (Capsicum baccatum). Horticultura Brasileira, 33(4), 415-421. https://doi.org/10.1590/S0102-053620150000400002

Novais, R. F., Neves, J. C. L., \& Barros, N. F. (1991). Experiments in controlled environment. In EMBRAPA-SEA (Ed.), Methods of research in soil fertility (pp. 189-253). Brasília, DF.

Nunes Júnior, E. S., Medeiros, J. F. de, Oliveira, F. de A. de, Lima, L. A., Bezerra, F. M. S., \& Alves, R. D. C. (2017). Nitrogen and potassium fertigation in bell pepper cultivated in greenhouse using fertigation managements. Revista Brasileira de Engenharia Agrícola e Ambiental, 21(3), 186-190. https://doi.org/ 10.1590/1807-1929/agriambi.v21n3p186-190

Núñez-Ramírez, F., González-Mendoza, D., Grimaldo-Juárez, O., \& Díaz, L. C. (2011). Nitrogen fertilization effect on antioxidants compounds in fruits of habanero chili pepper (Capsicum chinense). International Journal of Agriculture \& Biology, 13(5), 827-830.

Oliveira, F. de A. de, Duarte, S. N., Medeiros, J. F. de, Dias, N. da S., Silva, R. C. P. da, \& Lima, C. J. G. de S. (2013). Manejos da fertirrigação e doses de N e K no cultivo de pimentão em ambiente protegido. Revista Brasileira de Engenharia Agrícola e Ambiental, 17(11), 1152-1159. https://doi.org/10.1590/S1415-436620 13001100004

Pérez, D. V., Silva, J., Mattos, R., Regina, M., Laforet, C., \& Laia, C. R. De. (2013). In S. L. L. Beltrão, L. M. de Andrade, \& N. M. da Cunha Sette (Eds.), Brazilian Soil Classification System (3rd Revised and Expanded Edition). Brasília, DF: EMBRAPA.

Poiroux-Gonord, F., Bidel, L. P. R., Fanciullino, A.-L., Gautier, H., Lauri-Lopez, F., \& Urban, L. (2010). Health Benefits of Vitamins and Secondary Metabolites of Fruits and Vegetables and Prospects To Increase Their Concentrations by Agronomic Approaches. Journal of Agricultural and Food Chemistry, 58(23), 12065-12082. https://doi.org/10.1021/jf1037745

Raij, B. van, Andrade, J. C., Cantarela, H., \& Quaaggio, J. A. (2001). Chemical analysis for fertility evaluation of tropical soils. IAC. Fundação Cargill. 
Reich, P. B., Ellsworth, D. S., \& Walters, M. B. (1998). Leaf structure (specific leaf area) modulates photosynthesis-nitrogen relations: evidence from within and across species and functional groups. Functional Ecology, 12(6), 948-958. https://doi.org/10.1046/j.1365-2435.1998.00274.x

Rodrigues, P. (2016). Pepper: Of all tastes and flavors. A Lavoura, 716, 8-25.

Sarro, M. J., Gonzáles, L., \& Peñalosa, J. M. (1995). Response of pepper plants to different periods of nitrate and ammonium fertilization (pp. 439-446). I International Symposium on Solanacea for Fresh Market 412.

Seeram, N. P., Adams, L. S., Zhang, Y., Lee, R., Sand, D., Scheuller, H. S., \& Heber, D. (2006). Blackberry, black raspberry, blueberry, cranberry, red raspberry, and strawberry extracts inhibit growth and stimulate apoptosis of human cancer cells in vitro. Journal of Agricultural and Food Chemistry, 54(25), 9329-9339. https://doi.org/10.1021/jf061750g

Sharma, P., Jha, A. B., Dubey, R. S., \& Pessarakli, M. (2012). Reactive oxygen species, oxidative damage, and antioxidative defense mechanism in plants under stressful conditions. Journal of Botany, 2012, 1-26. https://doi.org/10.1155/2012/217037

Shukla, S., Anand Kumar, D., Anusha, S. V., \& Tiwari, A. K. (2016). Antihyperglucolipidaemic and anticarbonyl stress properties in green, yellow and red sweet bell peppers (Capsicum annuum L.). Natural Product Research, 30(5), 583-589. https://doi.org/10.1080/14786419.2015.1026343

Singleton, V. L., \& Rossi, J. A. (1965). Colorimetry of total phenolics with phosphomolybdic-phosphotungstic acid reagents. American Journal of Enology and Viticulture, 16(3), 144-158. Retrieved from http://www.ajevonline.org/content/16/3/144.abstract

Sora, G. T. S., Haminiuk, C. W. I., da Silva, M. V., Zielinski, A. A. F., Gonçalves, G. A., Bracht, A., \& Peralta, R. M. (2015). A comparative study of the capsaicinoid and phenolic contents and in vitro antioxidant activities of the peppers of the genus Capsicum: an application of chemometrics. Journal of Food Science and Technology, 52(12), 8086-8094. https://doi.org/10.1007/s13197-015-1935-8

Srinivasan, K. (2016). Biological activities of red pepper (Capsicum annuum) and its pungent principle capsaicin: A review. Critical Reviews in Food Science and Nutrition, 56(9), 1488-1500. https://doi.org/10.1080/ 10408398.2013.772090

Tundis, R., Menichini, F., Bonesi, M., Conforti, F., Statti, G., Menichini, F., \& Loizzo, M. R. (2013). Antioxidant and hypoglycaemic activities and their relationship to phytochemicals in Capsicum annuum cultivars during fruit development. LWT-Food Science and Technology, 53(1), 370-377. https://doi.org/10.1016/j.lwt. 2013.02.013

Valko, M., Jomova, K., Rhodes, C. J., Kuča, K., \& Musílek, K. (2016). Redox- and non-redox-metal-induced formation of free radicals and their role in human disease. Archives of Toxicology, 90(1), 1-37. https://doi.org/10.1007/s00204-015-1579-5

Wahyuni, Y., Ballester, A.-R., Sudarmonowati, E., Bino, R. J., \& Bovy, A. G. (2013). Secondary metabolites of Capsicum species and their importance in the human diet. Journal of Natural Products, 76(4), 783-793. https://doi.org/10.1021/np300898z

Wang, S. Y., \& Jiao, H. (2000). Scavenging capacity of berry crops on superoxide radicals, hydrogen peroxide, hydroxyl radicals, and singlet oxygen. Journal of Agricultural and Food Chemistry, 48(11), 5677-5684. https://doi.org/10.1021/jf000766i

Zimmer, A. R., Leonardi, B., Miron, D., Schapoval, E., Oliveira, J. R. De, \& Gosmann, G. (2012). Antioxidant and anti-inflammatory properties of Capsicum baccatum: From traditional use to scientific approach. Journal of Ethnopharmacology, 139(1), 228-233. https://doi.org/10.1016/j.jep.2011.11.005

\section{Copyrights}

Copyright for this article is retained by the author(s), with first publication rights granted to the journal.

This is an open-access article distributed under the terms and conditions of the Creative Commons Attribution license (http://creativecommons.org/licenses/by/4.0/). 